\title{
PREDIKSI EROSI, KLASIFIKASI KEMAMPUAN LAHAN DAN ARAHAN PENGGUNAAN LAHAN DI KECAMATAN BATURITI KABUPATEN TABANAN PROVINSI BALI
}

\author{
I Wayan Suarsana ${ }^{\left.1^{*}\right)}$, I Nyoman Merit ${ }^{2)}$, I Wayan Sandi Adnyana ${ }^{2)}$ \\ 1)ProgramMagister Ilmu Lingkungan Universitas Udayana \\ ${ }^{2)}$ Fakultas Pertanian Universitas Udayana \\ "Email: wynsuarsana@gmail.com
}

\begin{abstract}
Land resource damage caused by the land conversion and land use without regard to principles of conservation of soil and water. The damage resulted in the erosion is very high. Changes in land use without regard to principles of conservation of soil and water is currently happening in Baturiti District. Given this research can determine the level of erosion, soil and water conservation planning, land capability classification and proposed land use in Baturiti District.

Erosion prediction using USLE (Universal Soil Loss Equation) to estimate the rate of erosion and also to get an idea the determination of soil and water conservation measures appropriate to the region. Determination of the land capability classification method Arsyad (1989) is by classifying land capability to classify land capability class based on the value of the limiting factor of land that is adjusted with land capability classification criteria. Determining of the proposed land use using the scoring method by combining the slope factor of the field, the soil sensitivity of the against erosion and the intensity of daily rainfall. Soil sampling is done by taking a total of 19 soil samples from a unit of land.

The prediction results on each unit of land erosion in the area showed the level of erosion is very light covering an area of 11,70 ha, mild erosion area of 5.221,56 ha, erosion was an area of 88,10 ha, severe erosion area of 616.20 ha and very severe erosion area of 2.195,39 ha. Soil and water conservation measures required on land units with erosion prediction value exceeds the value erosion that can be tolerated so that the value could be below the value erosion erosion can be tolerated. Capability classification of the land in the study area consists of land capability class II with an area of 1489,39 ha, class III area of 827,39 ha, class IV with an area of 830.15 ha, class VI area of $1.373,79$ ha, class VII covering 1.453,92 ha, class VIII covering an area of 2.176,31 ha. Tutorial use of land for the forest department is directed to the protected forest area covering an area of 2.458,00 ha. Tutorial use of land outside the forest area to protected area 1079.81 ha (13,27\%), a buffer zone covering an area of $1.662,31$ ha, annual crop cultivation area covering an area of 844.86 ha and seasonal crops cultivation area covering an area of 2.087,97 ha.
\end{abstract}

Keyword: erosion; land capability; classification; proposed land use.

\section{PENDAHULUAN}

Kerusakan lingkungan pada dewasa ini semakin meningkat. Hal ini terjadi akibat aktivitas manusia dan faktor alam sehingga terjadi penurunan kualitas lingkungan. Salah satu bentuk kerusakan lingkungan yang nyata dapat dilihat saat ini adalah kerusakan yang diakibatkan faktor alam dan faktor aktivitas manusia berupa penggunaan lahan yang tidak tepat berupa erosi. Faktor yang berpengaruh terhadap erosi salah satunya adalah intensitas hujan, kemiringan lereng dan vegetasi penutupan tanah (Rahim, 2003). Tidak adanya tindakan konservasi tanah dan air akan mengakibatkan terjadinya erosi pada suatu lahan dan erosi merupakan interaksi kerja antara faktor iklim, vegetasi, tofografi, tanah dan manisia (Arsyad,1989). Diperlukan tindakan konservasi tanah dan air berupa arahan penggunan lahan berdasarkasn klasifikasi kemampuan lahan yang ada, sehingga nantinya akan bisa menekan ataupun mencegah erosi yang mungkin terjadi.Adapun tujuan dari klasifikasi kemampuan lahan menurut Sutanto, 2005 (dalam Adnyana dan As-syakur, 2011) yaitu memberikan arahan perencanaan dan pemanfaatan sumberdaya dan lingkungan yang sesuai dengan potensinya serta berkelanjutan. Menurut Hockensmith dan Steele, 1943 (dalam Murtianto, 2013) klasifikasi kemampuan lahan dapat diterapkan sebagai metode perencanaan penggunaan lahan.

Kecamatan Baturiti adalah salah satu wilayah yang mengalami perkembangan jumlah penduduk yang cukup signifikan. Adanya pertumbuhan jumlah penduduk ini telah mendorong terjadinya alih fungsi lahan.Pada tahun 2011 tata guna lahan untuk pertanian mencapai 5.726 hektar, sedangkan pada tahun 2014 tata guna lahan untuk pertanian mencapai 6.261 hektar dari luas keseluruhan yang mencapai 9.917 hektar (BPS Tabanan 2013). Status Lingkungan Hidup Daerah Kabupaten Tabanan (2014) mengemukakan persebaran jenis penggunaan lahan utama di Kecamatan Baturiti diperuntukan sebagai sawah dengan luas 1.808 hektar, lahan kering 8.109 hektar, perkebunan 591 hektar dan 
hutan 2.458 hektar. Kecamatan Baturiti memiliki lahan kritis seluas 2.312 hektar. Selain itu kecamatan Baturiti memiliki curah hujan yang cukup tinggi, yaitu rata - rata curah hujan tahunan yang mencapai 3400,9 mm per tahun (BPS Tabanan, 2013). Adanya alih fungsi lahan, tingginya intensitas curah hujan akan memperbesar laju erosi sehingga potensi terjadinya erosi sangat besar dan dapat memperbesar erosi yang telah terjadi sebelumnya. Oleh sebab itu diperlukan tindakan konservasi tanah dan air sehingga pemanfatan lahan yang ada tidak menimulkan kerusakan pada lahan itu sendiri.Penelitian ini dilakukan untuk mengetahui tingkat erosi yang terjadi, mengklasifikasi kemampuan lahan yang ada, serta dapat menghasilkan arahan penggunaan lahan yang tepat dan menjadi perencanaan konservasi tanah dan air di Kecamatan Baturiti, Kabupaten Tabanan.

\section{METODOLOGI}

Penelitian ini dilaksanakan di Kecamatan Baturiti, Kabupaten Tabanan. Pemilihan lokasi didasarkan atas wilayah Kecamatan Baturiti memiliki kemiringan lereng yang $0 \%$ sampai> 65 $\%$ dan memiliki curah hujan yang cukup tinggi. Waktu penelitian yaitu dari bulan Januari - Maret 2016.

Pengambilan sampel pada penelitian ini dilakukan dengan cara mengambil sampel pada unit lahan yang telah ditentukan dengan mempertimbangkan sifat - sifat tanah, panjang dan kemiringan lereng, pengelolaan tanaman yang sesuai dan tindakan konservasi tanah.

Kegiatan yang dilakukan dalam penelitian ini yang pertama adalah mendapatkan peta unit lahan daerah penelitian yaitu dengan menumpang-

Tabel 1.Satuan Unit Lahan Daerah Penelitian

\begin{tabular}{cccc}
\hline No Unit Lahan & Penggunaan Lahan & Kemiringan Lereng & Jenis Tanah \\
\hline 1 & Hutan & $>65 \%$ & Andosol \\
2 & Hutan & $45-65 \%$ & Andosol \\
3 & Hutan & $30-45 \%$ & Andosol \\
4 & Kebun & $>65 \%$ & Andosol \\
5 & Kebun & $45-65 \%$ & Andosol \\
6 & Kebun & $30-45 \%$ & Andosol \\
7 & Kebun & $15-30 \%$ & Andosol \\
8 & Kebun & $3-8 \%$ & Andosol \\
9 & Kebun & $15-30 \%$ & Latosol \\
10 & Kebun & $8-15 \%$ & Latosol \\
11 & Kebun & $0-3 \%$ & Latosol \\
12 & Sawah & $45-65 \%$ & Andosol \\
13 & Sawah & $30-45 \%$ & Andosol \\
14 & Sawah & $3-8 \%$ & Andosol \\
15 & Sawah & $45-65 \%$ & Latosol \\
16 & Sawah & $30-45 \%$ & Latosol \\
17 & Sawah & $15-30 \%$ & Latosol \\
18 & Sawah & $8-15 \%$ & Latosol \\
19 & Sawah & $0-3 \%$ & Latosol \\
\hline & & & \\
\hline & & & \\
\hline & & &
\end{tabular}

tindihkan peta jenis tanah, peta kemiringan lereng dan peta penggunaan lahan sehingga didapatakan peta unit lahan. Selanjutnya ditentukan titik sampel yang akan diambil sesuai dengan peta yang telah ditumpangtindihkan baik itu kemiringan lereng, jenis tanah dan penggunaan lahan.Satuan unit lahan daerah penelitian dan sebarnya sebanyak 19 unit lahan yang disajikan pada tabel 1 .

Rumusan USLE (Universal Soil Loss Equation) digunakan untuk menentukan prediksi erosi. Dalam menentukan nilai dari rumusan USLE maka terlebih dahulu perlu dilakukan analisis terhadap faktor faktor yang berpengaruh terhadap rumusan USLE yaitu: faktor erosivitas hujan (R), erodibilitas tanah (K), panjang dan kemiringan lereng (LS),pengelolaan tanaman (C) dan faktor pengelolaan tanah (P). Berdasarkan faktorerosivitas hujan, erodibilitas tanah, panjang dan kemiringan lereng, pengelolaan tanaman dan pengelolaan tanah tersebut, maka akan didapatkan nilai dari rumusan USLE, yang selanjutnya digunakan untuk menentukan seberapa besar erosi yang terjadi dan kelas tingkat bahaya erosi, serta nilai erosi yang ditoleransikan. Metode USLE dan erosi yang dapat ditoleransikan akan digunakan untuk mencari nilai dari perencanaan konservasi tanah dan air.

MetodeArsyad (1989) digunakan untuk menentukan klasifikasi kemampuan lahan. Dalam menentukan klasifikasi kemampuan lahan menggunakan metodeArsyad (1989) ini dilakukan dengan memperhitungkan nilai dari faktor pembatas yaitu faktor pembatas kemiringan lereng tingkat bahaya erosi, kedalaman efektif, tekstur tanah, drainase, batuan danancaman banjir. disesuaikan dengan kriteria klasifikasi kemampuan lahan yang ada.

Metode skoring digunakan untuk menentukan arahan penggunaan lahan. Dalam menggunakan metode ini dipertimbangkan tiga faktor, yaitu faktor lereng lapangan, faktor kepekaan jenis tanah terhadap erosi dan faktor intensitas curah hujan harian rata-rata. Penjumlahan dari ketiga faktor tersebut akan menentukan arahan penggunaan lahan dengan kreteria skor untuk masing - masing kawasan, yaitu skor untuk kawasan lindung $>175$, kawasan penyangga dengan skor antara $125-174$, dan dan kawasan budidaya tahunan dan semusim dengan skor $<124$, sedangkan untuk di dalam kawasan hutan akan menentukan nilai dari kawasan hutan lindung dengan skor $>175$, hutan produksi dengan skor antara 125-174 dan hutan suaka alam dan wisata ditetapkan berdasarkan kepentingan kebudayaan, ilmu pengetahuan, pelestarian plasma nutfah dan rekreasi.

Analisis data dilakukan melalui tiga cara yaitu analisis menggunakan metode USLE (Universal Soil Loss Equation) untuk menentukan tingkat erosi. Metode Arsyad (1989)digunakan untuk menentukan 
klasifikasi kemampuan lahan dan metode skoring digunanan untuk menentukan arahan penggunaan lahan

\section{HASIL DAN PEMBAHASAN}

\subsection{Prediksi Erosi}

Nilai faktor erosivitas hujan (R) di wilayah penelitian diperoleh dari analisis data curah hujan pada stasiun Baturiti dan stasiun Candikuning selama tujuh tahun terakhir dari tahun 2009 sampai 2015 dengan menggunakan rumus Bols (1978), yaitu nilai erosivitas berkisar antara 8,64 sampai 970,26 ton/ha/cm. Nilai erosivitas hujan (R) tahunan dari stasiun pencatat curah hujan stasiun Baturiti adalah sebesar 2.691,13 ton/ha/cm sedangkan pencatat curah hujan stasiun Candikuning adalah sebesar $3.342,59 \mathrm{ton} / \mathrm{ha} / \mathrm{cm}$.Nilai rata - rata dari erosivitas hujan $(\mathrm{R})$ tahunan dari kedua stasiun yang ada yaitu sebesar3016,86 ton $/ \mathrm{ha} / \mathrm{cm}$.

Nilai erodibilitas tanah (K) di wilayah penelitian bervariasi berkisar antara 0,19 sampai 0,64 dengan kriteria rendah sampai sangat tinggi. Nilai erodibilitas tanah yang bervariasi disebabkan oleh keragaman nilai permeabilitas tanah, tekstur tanah dan kandungan bahan organik pada setiap unit lahan di wilayah penelitian. Nilai faktor panjang lereng dan kemiringan lereng (LS) di wilayah penelitian berkisar antara 0,35 sampai 23,00, dimana topografi wilayah penelitian dari landai sampai sangat curam dengan panjang lereng berkisar antara 5 sampai 73 meter, sedangkan kemiringan lereng berkisar antara 1 sampai $69 \%$. Nilai hasil pengelolaan tanaman (C) di wilayah penelitian berkisar antara 0,001 sampai 0,3 dan untuk nilai tindakan konservasi tanah $(\mathrm{P})$ berkisar antara 0,04 sampai 1,00. Nilai gabungan pengelolaan tanaman dengan tindakan konservasi tanah (CP) di wilayah penelitian yaitu berkisar antara 0,0004 sampai 0,105 .

Rumus USLE (Universal Soil LossEquation) yang dikembangkan oleh Wischmeier dan Smith (1978)digunakan untuk mendapatkan nilai prediksi erosi (A) pada setiap unit lahan di wilayah penelitian, sehingga diperoleh hasil nilai erosi rata - rata tahunan wilayah penelitian (Tabel 2). Berdasarkan hasil perhitungan menggunakan rumus USLE diperoleh nilai prediksi erosi di Kecamatan Baturiti berkisar antara 0,18 ton/ha/tahun sampai 2.614,94 ton/ha/tahun, dengan kriteria sangat ringan sampai sangat berat.

Erosi sangat ringan terjadi pada unit lahan lahan 3 seluas 11,70 ha $(0,14 \%)$ dengan penggunaan lahan berupa hutan.Erosi ringan terjadi pada unit lahan $1,2,13,14,16,17,18$, dan 19 seluas 5.221,56 ha $(64,20 \%)$ dengan penggunaan lahan berupa hutandan sawah. Erosi sedang terjadi pada unit lahan 12 seluas 88,10 ha (1.08\%) dengan penggunaan lahan berupa sawah. Rendahnya nilai erosi yang terjadi disebabkan oleh kecilnya nilai CP dikarenakan kerapatan tajuk tanaman sangat tinggi yang dapat menghalau butiran hujan yang jatuh di permukaan tanah sehingga dapat mengurangi laju erosi yang terjadi.

Erosi berat terjadi pada unit 8, 11, dan 15 seluas 616,20 ha $(7,58 \%)$ dengan penggunaan lahan berupa kebun campuran dan sawah. Erosi sangat berat terjadi pada unit lahan 4, 5, 6, 7, 9, dan 10 seluas $2.195,39(27,00 \%)$ dengan penggunaan lahan berupa kebun campuran.Penyebab terjadinya erosi yang berat dan sangat berat ini dikarenakan nilai faktor LS dan CP yang cukup tinggi, dimana kerapatan penutup tanahnya tidak sesuai atau cocok dan tidak disertai dengan tindakan konservasi tanah yang sesuai. Adanya ketidaksesuaian pada kerapatan ataupun jenis penutup tanah dan tindakan konservasi tanah yang dilakukan akan berpengaruh terhadap kerusakan permukaan tanah, dimana hal ini akan memberikan peluang terhadap butiran butiran air hujan untuk merusak permukaan tanah, dan hal ini rentan terjadi terutama pada unit lahan yang tidak mempunyai kerapatan tanaman yang tinggi. Selain nilai faktor CP yang tinggi juga dipengaruhi oleh nilai faktor LS yang juga tinggi, dimana unit lahan dengan kemiringan lereng yang tidak terlalu curam juga akan dapat mengalami erosi yang tinggi apabila memiliki nilai CP yang tinggi karena dengan kerapatan tanaman yang sedang ataupun jarang menutupi permukaan tanah maka akan dapat memperbesar laju erosi.

Pengelolaan tanaman dan tindakan konservasi tanah perlu dilakukan dan ditingkatkan untuk menekan terjadinya erosi yang mungkin terjadi. Tanaman dapat membantu mengurangi kerusakan tanah dari tumbukan air hujan yang jatuh, sedangkan tindakan konservasi tanah dilakukan agar dapat membantu mengurangi laju aliran permukaan sehingga mengurangi tingkat erosi.

Hasil perhitungan erosi yang dapat ditoleransikan (T) pada masing-masing unit lahan di wilayah penelitian (Tabel 3). Dari tabel tersebut menunjukkan nilai kedalaman tanah, faktor kedalaman tanah, umur guna tanah, dan berat volume tanah.

Berdasarkan Tabel 3 diketahui bahwa perhitungan erosi yang ditoleransikan (T) diperoleh hasil berkisar antara 18,67 ton/ha/tahunsampai 30,53 ton/ha/tahun. Perbedaan hasil erosi yang ditoleransikan (T) disebabkan oleh kedalaman efektif tanah dan berat volume tanah tiap-tiap sampel unit lahan. Nilai $\mathrm{T}$ yang terendah berada pada unit lahan 15 dengan penggunaan lahan berupa sawah beririgasi, sedangkan nilai $\mathrm{T}$ yang tertinggi berada pada unit lahan 3 dengan penggunaahn lahan berupa hutan tanpa tindakan konservasi tanah. 
Tabel 2. Prediksi Erosi Rata - Rata Tahunan di Kecamatan Baturiti

\begin{tabular}{llllllcc}
\hline \multirow{2}{*}{ No. Unit Lahan } & \multicolumn{3}{c}{ Nilai } & & Prediksi Erosi (A) & Tingkat Erosi \\
\cline { 2 - 5 } & $\mathbf{R}$ & $\mathbf{K}$ & $\mathbf{L S}$ & $\mathbf{C}$ & $\mathbf{P}$ & \\
\hline 1 & 3016,86 & 0,23 & 23,00 & 0,001 & 1,00 & 15,96 & Ringan \\
2 & 3016,86 & 0,19 & 17,10 & 0,001 & 1,00 & 9,80 & Ringan \\
3 & 3016,86 & 0,22 & 9,28 & 0,001 & 1,00 & 6,16 & Sangat Ringan \\
4 & 3016,86 & 0,23 & 17,41 & 0,3 & 0,35 & $1.268,44$ & Sangat Berat \\
5 & 3016,86 & 0,50 & 16,51 & 0,3 & 0,35 & $2.614,94$ & Sangat Berat \\
6 & 3016,86 & 0,30 & 10,83 & 0,3 & 0,35 & $1.029,19$ & Sangat Berat \\
7 & 3016,86 & 0,29 & 5,81 & 0,3 & 0,35 & 533,73 & Sangat Berat \\
8 & 3016,86 & 0,22 & 1,32 & 0,3 & 0,15 & 39,42 & Berat \\
9 & 3016,86 & 0,39 & 4,35 & 0,3 & 0,35 & 537,40 & Sangat Berat \\
10 & 3016,86 & 0,41 & 2,56 & 0,1 & 1,00 & 316,65 & SangatBerat \\
11 & 3016,86 & 0,32 & 1,60 & 0,1 & 1,00 & 154,46 & Berat \\
12 & 3016,86 & 0,32 & 15,96 & 0,01 & 0,15 & 23,11 & Sedang \\
13 & 3016,86 & 0,56 & 9,80 & 0,01 & 0,04 & 6,62 & Ringan \\
14 & 3016,86 & 0,33 & 1,39 & 0,01 & 0,15 & 2,07 & Ringan \\
15 & 3016,86 & 0,35 & 15,00 & 0,01 & 0,15 & 23,76 & Berat \\
16 & 3016,86 & 0,29 & 7,42 & 0,01 & 0,15 & 9,74 & Ringan \\
17 & 3016,86 & 0,40 & 6,25 & 0,01 & 0,04 & 3,02 & Ringan \\
18 & 3016,86 & 0,64 & 1,92 & 0,01 & 0,04 & 1,48 & Ringan \\
19 & 3016,86 & 0,44 & 0,35 & 0,01 & 0,04 & 0,18 & Ringan \\
\hline
\end{tabular}

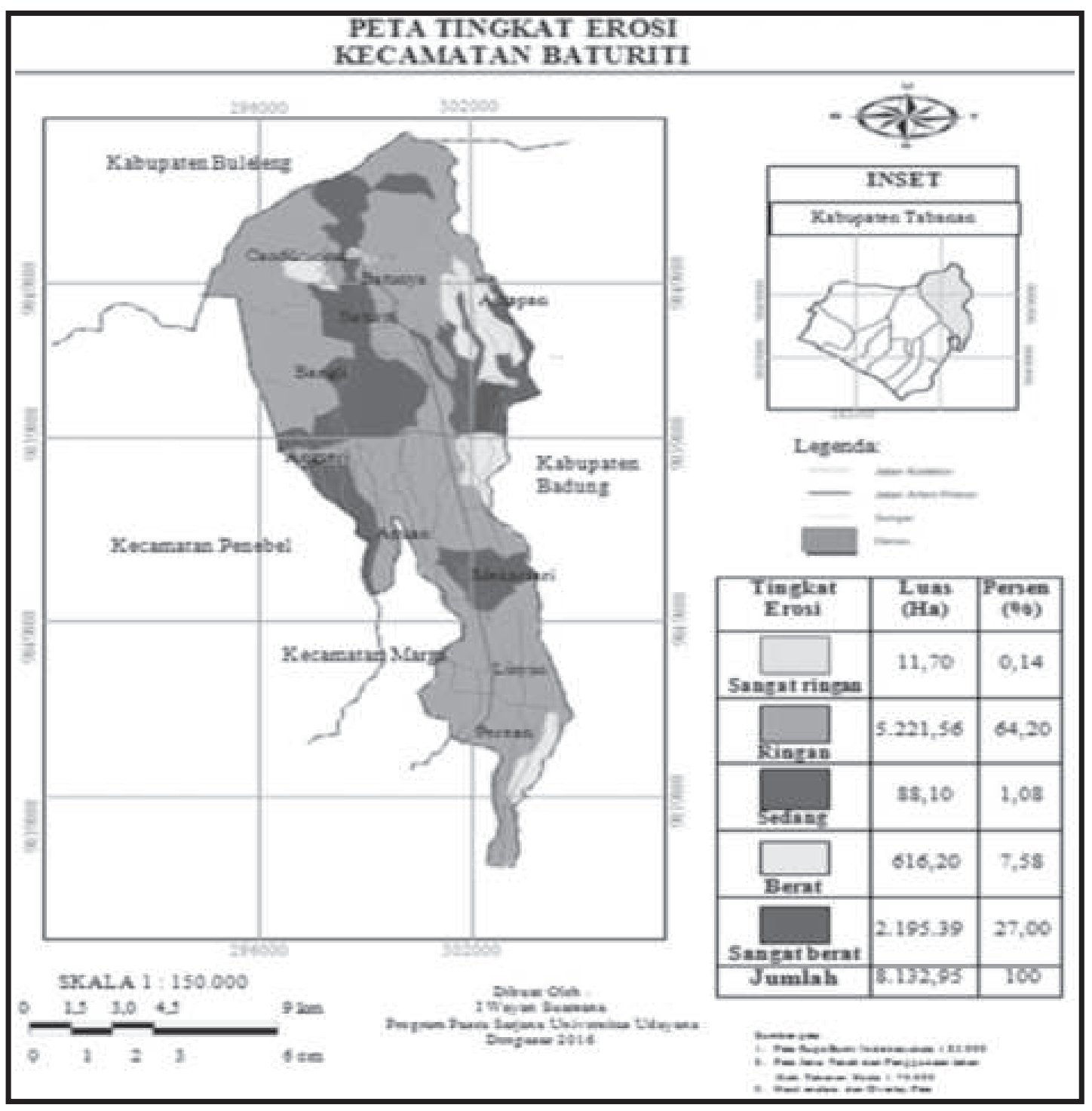

Gambar 1. Peta Tingkat Erosi Kecamatan Baturiti 
Tabel 3. Erosi yang Dapat Ditoleransikan (T) di Kecamatan Baturiti

\begin{tabular}{ccccccc}
\hline No. Unit Lahan & $\begin{array}{c}\text { Kedalaman } \\
\text { Tanah(mm) }\end{array}$ & $\begin{array}{c}\text { Sub Grup } \\
\text { Tanah }\end{array}$ & $\begin{array}{c}\text { Faktor } \\
\text { Kedalaman }\end{array}$ & $\begin{array}{c}\text { Umur Guna } \\
\text { Tanah (Tahun) }\end{array}$ & $\begin{array}{c}\text { Berat Volume } \\
\left.\text { (gr/cm } \mathbf{s}^{3}\right)\end{array}$ & $\begin{array}{c}\text { Erosi yang Dapat } \\
\text { Ditoleransikan } \\
\text { (T)(ton/ha/thn) }\end{array}$ \\
\hline 1 & 950 & Andept & 1,00 & 300 & 0,879 & 27,86 \\
2 & 900 & Andept & 1,00 & 300 & 0,894 & 26,82 \\
3 & 950 & Andept & 1,00 & 300 & 0,963 & 30,53 \\
4 & 700 & Andept & 1,00 & 300 & 1,118 & 26,05 \\
5 & 900 & Andept & 1,00 & 300 & 0,973 & 29,19 \\
6 & 700 & Andept & 1,00 & 300 & 0,996 & 23,21 \\
7 & 850 & Andept & 1,00 & 300 & 1,013 & 28,67 \\
8 & 600 & Andept & 1,00 & 300 & 1,060 & 21,20 \\
9 & 600 & Aquept & 0,95 & 300 & 1,065 & 20,23 \\
10 & 750 & Aquept & 0,95 & 300 & 0,949 & 22,49 \\
11 & 800 & Aquept & 0,95 & 300 & 1,100 & 27,83 \\
12 & 650 & Andept & 1,00 & 300 & 1,027 & 22,85 \\
13 & 650 & Andept & 1,00 & 300 & 0,990 & 21,48 \\
14 & 600 & Andept & 1,00 & 300 & 1,250 & 25,00 \\
15 & 550 & Aquept & 0,95 & 300 & 1,073 & 18,67 \\
16 & 700 & Aquept & 0,95 & 300 & 1,124 & 24,95 \\
17 & 650 & Aquept & 0,95 & 300 & 1,070 & 22,04 \\
18 & 650 & Aquept & 0,95 & 300 & 1,100 & 1,044 \\
19 & 600 & Aquept & 0,95 & 300 & 19,84 \\
\hline
\end{tabular}

Tabel 4. Perencanaan Penggunaan Lahan dan Konservasi Tanah dan Air di Kecamatan Baturiti

\begin{tabular}{|c|c|c|c|c|c|c|c|}
\hline $\begin{array}{l}\text { No Unit } \\
\text { Lahan }\end{array}$ & $\begin{array}{l}\text { Kondisi Lahan Saaat } \\
\text { ini }\end{array}$ & $\begin{array}{l}\text { Alternatif Penggunaan } \\
\text { Lahan dan Konservasi } \\
\text { Tanah dan Air }\end{array}$ & $\begin{array}{l}\text { Nilai } \\
\text { Faktor } \\
\text { C }\end{array}$ & $\begin{array}{l}\text { Nilai } \\
\text { Faktor } \\
\text { P }\end{array}$ & $\begin{array}{c}\text { Besar } \\
\text { Erosi } \\
\text { Sebelum } \\
\text { Perencan } \\
\text { aan } \\
\text { (ton/hal } \\
\text { tahun) }\end{array}$ & $\begin{array}{c}\text { Besar } \\
\text { Erosi } \\
\text { Setelah } \\
\text { Perencan } \\
\text { aan } \\
\text { (ton/hal } \\
\text { tahun) }\end{array}$ & $\begin{array}{c}\text { Erosi yang Dapat } \\
\text { Ditoleransikan (T) } \\
\text { (ton/ha } \\
\text { /tahun) }\end{array}$ \\
\hline 1 & $\begin{array}{c}\text { Kebun campuran, } \\
\text { penutup tanah } \\
\text { bervariasi dengan } \\
\text { kerapatan sedang, } \\
\text { kemiringan lereng } 68 \% \text {, } \\
\text { teras bangku kontruksi } \\
\text { buruk. }\end{array}$ & $\begin{array}{l}\text { Kebun campuran, tajuk } \\
\text { bertingkat, penutup } \\
\text { tanah bervariasi dengan } \\
\text { kerapatan tinggi, } \\
\text { penanaman menurut } \\
\text { kontur, teras bangku } \\
\text { kontruksi baik, mulsa } \\
\text { sisa tanaman } 6 \\
\text { ton/ha/tahun, }\end{array}$ & 0,1 & 0,0108 & $1.268,44$ & 13,05 & 26,05 \\
\hline 2 & $\begin{array}{l}\text { Kebun campuran } \\
\text { penutup tanah } \\
\text { bervariasi dengan } \\
\text { kerapatan sedang, } \\
\text { kemiringan lereng } 57 \\
\% \text {, teras bangku } \\
\text { kontruksi buruk. }\end{array}$ & $\begin{array}{l}\text { Kebun campuran, tajuk } \\
\text { bertingkat, penutup } \\
\text { tanah bervariasi dengan } \\
\text { kerapatan tinggi, } \\
\text { penanaman menurut } \\
\text { kontur, teras bangku } \\
\text { kontruksi baik, mulsa } \\
\text { sisa tanaman } 6 \\
\text { ton/ha/tahun } \\
\end{array}$ & 0,1 & 0,0108 & $2.614,94$ & 26,90 & 29,19 \\
\hline 3 & $\begin{array}{c}\text { Kebun campuran } \\
\text { penutup tanah } \\
\text { bervariasi dengan } \\
\text { kerapatan sedang, } \\
\text { kemiringan lereng } 40 \\
\%, \text { teras bangku } \\
\text { kontruksi buruk }\end{array}$ & $\begin{array}{l}\text { Kebun campuran, tajuk } \\
\text { bertingkat, penutup } \\
\text { tanah bervariasi dengan } \\
\text { kerapatan tinggi, } \\
\text { penanaman menurut } \\
\text { kontur, teras bangku } \\
\text { kontruksi baik, mulsa } \\
\text { sisa tanaman } 6 \\
\text { ton/ha/tahun } \\
\end{array}$ & 0,1 & 0,0108 & $1.029,19$ & 10,58 & 23,21 \\
\hline 4 & $\begin{array}{c}\text { Kebun campuran } \\
\text { penutup tanah } \\
\text { bervariasi dengan } \\
\text { kerapatan sedang, } \\
\text { kemiringan lereng } 23 \\
\% \text {, teras bangku } \\
\text { kontruksi buruk }\end{array}$ & $\begin{array}{c}\text { Kebun campuran, tajuk } \\
\text { bertingkat, penutup } \\
\text { tanah bervariasi, } \\
\text { kerapatan tinggi dan } \\
\text { teras bangku kontruksi } \\
\text { baik }\end{array}$ & 0,1 & 0,04 & 533,73 & 20,33 & 28,67 \\
\hline
\end{tabular}




\begin{tabular}{|c|c|c|c|c|c|c|c|}
\hline $\begin{array}{l}\text { No Unit } \\
\text { Lahan }\end{array}$ & $\begin{array}{l}\text { Kondisi Lahan Saaat } \\
\text { ini }\end{array}$ & $\begin{array}{l}\text { Alternatif Penggunaan } \\
\text { Lahan dan Konservasi } \\
\text { Tanah dan Air }\end{array}$ & $\begin{array}{l}\text { Nilai } \\
\text { Faktor } \\
\text { C }\end{array}$ & $\begin{array}{l}\text { Nilai } \\
\text { Faktor } \\
\text { P }\end{array}$ & $\begin{array}{c}\text { Besar } \\
\text { Erosi } \\
\text { Sebelum } \\
\text { Perencan } \\
\text { aan } \\
\text { (ton } / \text { hal } \\
\text { tahun) } \\
\end{array}$ & $\begin{array}{l}\text { Besar } \\
\text { Erosi } \\
\text { Setelah } \\
\text { Perencan } \\
\text { aan } \\
\text { (ton/hal } \\
\text { tahun) } \\
\end{array}$ & $\begin{array}{c}\text { Erosi yang Dapat } \\
\text { Ditoleransikan (T) } \\
\text { (ton/ha } \\
\text { ttahun) }\end{array}$ \\
\hline 5 & $\begin{array}{l}\text { Kebun campuran } \\
\text { penutup tanah } \\
\text { bervariasi dengan } \\
\text { kerapatan sedang, } \\
\text { kemiringan lereng } 5 \% \text {, } \\
\text { teras bangku kontruksi } \\
\text { sedang }\end{array}$ & $\begin{array}{l}\text { Kebun campuran, tajük } \\
\text { bertingkat, penutup } \\
\text { tanah bervariasi, } \\
\text { kerapatan tinggi dan } \\
\text { teras bangku kontruksi } \\
\text { baik }\end{array}$ & 0,1 & 0,04 & 39,42 & 3,50 & 21,20 \\
\hline 6 & $\begin{array}{c}\text { Kebun campuran } \\
\text { penutup tanah } \\
\text { bervariasi dengan } \\
\text { kerapatan sedang, } \\
\text { kemiringan lereng } 20 \% \text {, } \\
\text { teras bangku kontruksi } \\
\text { buruk }\end{array}$ & $\begin{array}{l}\text { Kebun campuran, tajuk } \\
\text { bertingkat, penutup } \\
\text { tanah bervariasi dengan } \\
\text { kerapatan tinggi, } \\
\text { penanaman menurut } \\
\text { kontur, teras bangku } \\
\text { kontruksi baik mulsa } \\
\text { sisa tanaman } 6 \\
\text { ton/ha/tahun } \\
\end{array}$ & 0,1 & 0,009 & 537,40 & 4,61 & 20,23 \\
\hline 7 & $\begin{array}{c}\text { Kebun campuran, } \\
\text { penutup tanah } \\
\text { hervariasi dengan } \\
\text { kerapatan tinggi, } \\
\text { kemiringan lereng } 12 \% \text {, } \\
\text { tanpa tindakan } \\
\text { konservasi tanah } \\
\end{array}$ & $\begin{array}{c}\text { Kebun campuran, tajuk } \\
\text { bertingkat, penutup } \\
\text { tanah bervariasi. } \\
\text { kerapatan tinggi dan } \\
\text { teras bangku kontruksi } \\
\text { baik }\end{array}$ & 0.1 & 0,04 & 316,65 & 12,66 & 22,49 \\
\hline 8 & $\begin{array}{l}\text { Kebun campuran, } \\
\text { penutup tanah } \\
\text { bervariasi dengan } \\
\text { kerapatan tinggi, } \\
\text { kemiringan lereng } 2 \%, \\
\text { tanpa tindakan } \\
\text { konservasi tanah } \\
\end{array}$ & $\begin{array}{c}\text { Kebun campuran, tajuk } \\
\text { bertingkat, penutup } \\
\text { tanah bervariasi, } \\
\text { kerapatan tinggi dan } \\
\text { teras bangku kontruksi } \\
\text { baik }\end{array}$ & 0,1 & 0,04 & 154,46 & 6,18 & 27,83 \\
\hline 9 & $\begin{array}{c}\text { Sawah beririgasi } \\
\text { dengan kemiringan } \\
\text { lereng, } 52 \% \\
\text { teras bangku kontruksi } \\
\text { sedang } \\
\end{array}$ & $\begin{array}{c}\text { Sawah beririgasi } \\
\text { dengan teras bangku } \\
\text { kontruksi baik }\end{array}$ & 0,1 & 0,04 & 23,11 & 6,16 & 22,85 \\
\hline 10 & $\begin{array}{c}\text { Sawah beririgasi } \\
\text { dengan kemiringan } \\
\text { lereng, } 50 \% \\
\text { teras bangku kontruksi } \\
\text { sedang } \\
\end{array}$ & $\begin{array}{c}\text { Sawah beririgasi } \\
\text { dengan teras bangku } \\
\text { kontruksi baik }\end{array}$ & 0,1 & 0,04 & 23,76 & 6,33 & 18,67 \\
\hline
\end{tabular}

Alternatif penggunaan lahan untuk nilai CP (Tabel 4) agar nilai prediksi erosi (A) bisa beradadibawah nilai erosi yang dapat ditoleransikan (T).

Pada unit lahan 4,5, 6 dan 9 penggunaan lahan saat ini adalah kebun campuran, alternatif perencanaan konservasi tanah dan air dilakukan dengan cara membuat kebun campuran, tajuk bertingkat, penutup tanah bervariasi dengan kerapatan tinggi, penanaman menurut kontur, teras bangku kontruksi baik dan penggunaan mulsa sisa tanaman 6 ton/ha/tahun sehingga mendapatkan nilai C sebesar 0,1 dan nilai $P$ sebesar 0,0108. Penurunan nilai erosi terjadi setelah dilakukannya tindakan konservasi tanah dan air, dimana pada unit lahan 4 sebelum dilakukan tindakan konservasi nilai erosi sebesar 1.268, ton/ha/tahun dan setelah dilakukan tindakan konservasi menjadi 13,05 ton/ha/tahun. Pada unit lahan5 sebelum dilakukan tindakan konservasi nilai erosi sebesar 2.614,94 ton/ha/tahun dan sesudah dilakukan tindakan konservasi menjadi 26,90 ton/ha/tahun. Pada unit lahan 6 sebelum dilakukan tindakan konservasi nilai erosi sebesar $1.029,19 \mathrm{ton} / \mathrm{ha} / \mathrm{tahun}$ dan setelah dilakukan tindakan konservasi menjadi 10,58 ton/ha/tahun. Pada unit lahan 9 sebelum dilakukan tindakan konservasi nilai erosi sebesar 537,40ton/ha/tahun dan setelah dilakukan tindakan konservasi menjadi 4,61 ton/ha/tahun.

Pada unit lahan 7,8,10 dan 11 penggunaan lahan saat ini berupa kebun campuran,adapun alternatif perencanaan konservasi tanah dan air yang dapat dilakukan yaitu dengan cara membuat kebun campuran, tajuk bertingkat, penutup tanah 
bervariasi dengan kerapatan tinggi dengan teras bangku kontruksi baik, sehingga diperoleh nilai $\mathrm{C}$ sebesar 0,1 dan Nila P sebesar 0,04 dan 0,009. Penurunan nilai erosi terjadi setelah dilakukannya tindakan konservasi tanah dan air, pada unit lahan 7 sebelum dilakukan tindakan konservasi nilai erosi sebesar 533,73 ton/ha/tahun dan setelah dilakukan tindakan konservasi menjadi 20,33 ton/ha/tahun. Pada unit lahan 8 sebelum dilakukan tindakan konservasi nilai erosi sebesar 39,42 ton/ha/tahun dan setelah dilakukan tindakan konservasi menjadi 3,50 ton/ha/tahun. Untuk unit lahan 10 nilai erosi sebelum dilakukan perencanaan konservasi tanah dan air sebesar 316,65 ton/ha/tahun dan setelah dilakukan tindakan konservasi menjadi 12,66 ton/ha/tahun. Begitu pula dengan unit lahan 11 sebelum dilakukan tindakan konservasi nilai erosi sebesar 154,46 ton/ ha/tahun dan setelah dilakukan tindakan konservasi menjadi 6,18 ton/ha/tahun.

Pada unit lahan 12 dan 15 dengan penggunaan lahan saat ini berupa sawah beririgasi,adapun alternatif perencanaan konservasi tanah dan air yang dapat dilakukan yaitu dengan cara mengubah faktor pengelolaan tanah berupa sawah beririgasi dengan teras kontruksi baik, sehingga didapatkan nilai $\mathrm{C}$ sebesar 0,1 dan nilai $\mathrm{P}$ sebesar 0,4 . Penurunan nilai erosi terjadi setelah dilakukannya tindakan konservasi tanah dan air, dimana sebelum dilakukan tindakan konservasi nilai erosi pada unit lahan 12 sebesar 23,11 ton/ha/tahun dan setelah dilakukan tindakan konservasi menjadi 6,16 ton/ha/tahun. Begitu pula dengan unit lahan 15 sebelum dilakukan tindakan konservasi nilai erosi sebesar 23,76 ton/ha/ tahun dan setelah dilakukan tindakan konservasi menjadi 6,33 ton/ha/tahun.

\subsection{Klasifikasi Kemampuan Lahan}

Berikut klasifikasi kemampuan lahanyang ada di Kecamatan Baturitidengan menggunakan metode Arsyad (1989) yaitu dengan menggolongkan kelas kemampuan lahan berdasarkan nilai dari faktor pembatas yang dimiliki masing - masing unit lahan, (Tabel 5).

Klasifikasi kemapuan lahan di Kecamatan Baturiti dapat dikelompokan menjadi kelas II, III, IV, VI, VII dan kelas VIII). Sebaran kemampuan lahan kelas IIe dengan luas 413,30 ha (5,09\%)dengan faktor pembatas utama kepekaan erosi yang agak tinggi yang terdapat di Desa Batunya, Candikuning dan Antapan. Kemampuan lahan kelas IIs terdapat pada unit lahan 11 dengan luas 98,78 ha $(1,21 \%)$ dengan faktor pembatas tekstur tanah yang kasar yang terdapat di Desa Perean. Kemampuan lahan kelas IIew dengan luas 977 ha $(12,02 \%)$ dengan faktor pembatas utama kepekaan erosi yang agak tinggi dan drainase yang agak buruk terdapat di Desa Candikuning, Batunya dan Luwus.

Sebaran kemampuan lahan kelas IIIe yaitu pada unit lahan 10 dengan luas 184,83 ha (2,27\%) dengan faktor pembatas utama yaitu kepekaan erosi yang tinggi yang terdapat di Desa Mekarsari. Sedangkan kemampuan lahan kelas IIIew terdapat pada unit lahan 18 dengan luas 624,56 ha (7,68\%) dengan faktor pembatas utama berupa kepekaan erosi yang sangat tinggi dan drainase yang agak buruk yang tersebar di Desa Mekarsari, Luwus dan Perean.

Sebaran kemampuan lahan kelas IVe yaitu pada unit lahan no 7, 9 dan 17 seluas 830,15 ha (10,21\%) dengan faktor pembatas berupa kepekaan erosi yang tinggi pada masing - masing unit lahannya. Kemampuan lahan kelas IVe tersebar di Desa Candikuning, Angseri dan Apuan. Sebaran kemampuan lahan kelas VIe tersebar pada unit lahan no $3,6,13$, dan 16 seluas $1.373,79$ ha (16,89\%) dengan faktor pembatas utama yaitu ancaman erosi yang cukup tinggi akibat lereng yang agak curam yaitu 30 sampai $45 \%$ dan kepekaan erosi yang sangat tinggi. Sebaran kemampuan lahan kelas VIe tersebar di Desa Batunya, Candikuning, Bangli dan Baturiti.

Sebaran kemampuan lahan kelas VIIe yaitu terdapat pada unit lahan no 2, 5, 12 dan 15 seluas $1.453,92$ ha $(16,89 \%)$ dengan faktor pembatas berupa ancaman erosi yang sangat tinggi dan kemiringan lereng yang curam (45-65\%). Kemampuan lahan kelas VIIe tersebar di Desa Bangli, Candikuning, Angseri dan Antapan. Sebaran kemampuan lahan kelas VIIIe yaitu pada unit lahan no 1 dan 4 dengan luas $2.176,31$ ha $(26,76 \%)$ dengan faktor pembatas berupa kemiringan lereng yang sangat curam (>65 \%) dan tersebar di Desa Bangli, Angseri, Candikuning dan Antapan.

\subsection{Arahan Penggunaan Lahan}

Metode skoring untuk arahan penggunaan lahantersebut dipengaruhi oleh tiga faktor, yaitu faktorlereng lapangan, faktor kepekaan jenis tanahterhadap erosi, dan faktor intensitas curah hujanharian rata-rata. Hasil penjumlahan dari ketigafaktor tersebut akan dapat menentukan arahanpenggunaan lahan di masing-masing unit lahan (Tabel 6).

Dari hasil penelitian di Kecamatan Baturiti diperoleh bahwa penetapan arahan penggunaan lahan ada dua yaitu kawasan dalam hutan dan kawasan luar hutan. Untuk kawasan dalam hutan arahan penggunaan lahan berupa hutan lindung, sedangkan untuk diluar kawasan hutan terdapat empat jenis arahan penggunaan lahan yaitu: kawasan lindung, kawasan penyangga, kawasan budidaya tanaman tahunan dan kawasan budidaya tanaman semusim.

Kawasan dalam hutan merupakan kawasan hutan lindung. Penggunaan lahan hutan alam yaitu pada unit lahan 1, 2, dan 3 yang tersebar di wilayah Desa Candikuning, Bangli, Angseri, Batunya dan Antapan dengan kemiringan lereng berkisar 40 sampai 69 \% yang merupakan termasuk arahan penggunaan lahan berupa hutan lindung. 
Tabel 5. Kelas Kemampuan Lahan di Kecamatan Baturiti

\begin{tabular}{ccccl}
\hline $\begin{array}{c}\text { No Unit } \\
\text { Lahan }\end{array}$ & $\begin{array}{c}\text { Kelas Kemampuan } \\
\text { Lahan }\end{array}$ & $\begin{array}{c}\text { Sub Kelas } \\
\text { Kemampuan Lahan }\end{array}$ & $\begin{array}{c}\text { Faktor } \\
\text { Pembatas }\end{array}$ & \multicolumn{1}{c}{ Keterangan } \\
\hline 1 & VIII & VIIle & Erosi & Ancaman erosi sangat tinggi karena lereng yang sangat curam \\
2 & VII & VIle & Erosi & Ancaman erosi sangat tinggi karena lereng yang curam \\
3 & VI & Vle & Erosi & Ancaman erosi cukup tinggi karena lereng yang agak curam \\
4 & VIII & VIIle & Erosi & Ancaman erosi sangat tinggi karena lereng yang sangat curam \\
5 & VII & VIle & Erosi & Kepekaan erosi tinggi dan juga ancaman erosi yang sangat \\
& & & & tinggi karena lereng yang curam \\
6 & VI & Vle & Erosi & Ancaman erosi tinggi karena lereng yang agak curam \\
7 & IV & IVe & Erosi & Kepekaan erosi yang agak tinggi \\
8 & II & IIs & Tekstur & Tekstur tanah yang kasar \\
9 & IV & IVe & Erosi & Kepekaan erosi yang agak tinggi \\
10 & III & IIle & Erosi & Kepekaan erosi yang tinggi \\
11 & II & Ile & Erosi & Kepekaan erosi yang agak tinggi \\
12 & VII & VIle & Erosi & Kepekaan erosi yang agak tinggi \\
13 & VI & Vle & Erosi & Kepekaan erosi yang sangat tinggi \\
14 & II & Ilew & Erosi dan drainase & Kepekaan erosi erosi agak tinggi dan drainase yang agak buruk \\
15 & VII & VIle & Erosi & Kepekaan erosi yang agak tinggi \\
16 & VI & Vle & Erosi & Ancaman erosi yang cukup tinggi karena lereng yang \\
& & & & agak curam \\
17 & IV & IVe & Erosi & Kepekaan erosi yang agak tinggi \\
18 & III & IIlew & Erosi dan drainase & Kepekaan erosi yang sangat tinggi dan drainase yang \\
19 & II & agak buruk & Kepekaan erosi yang tinggi dan drainase yang agak buruk \\
\hline
\end{tabular}

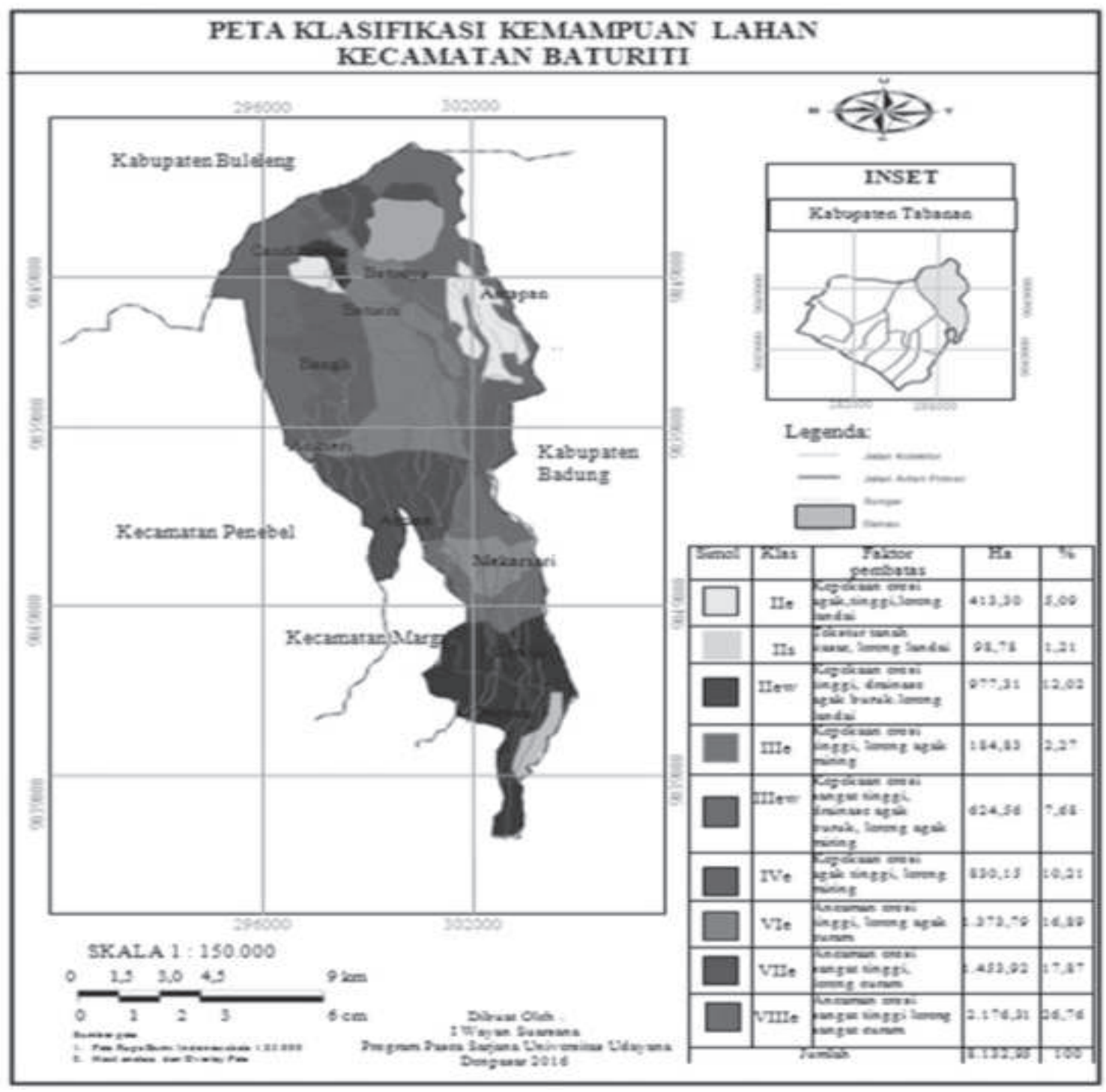

Gambar 2. Peta Klasifikasi Kemampuan Lahan Kecamatan Baturiti 
Tabel 6. Arahan Penggunaan Lahan di Kecamatan Baturiti

\begin{tabular}{|c|c|c|c|c|c|c|c|c|c|}
\hline \multirow[t]{2}{*}{$\begin{array}{l}\text { No Unit } \\
\text { Lahan }\end{array}$} & \multicolumn{2}{|c|}{$\begin{array}{l}\text { Kemiringan } \\
\text { lereng }\end{array}$} & \multicolumn{2}{|c|}{$\begin{array}{l}\text { Jenis Tanah } \\
\text { Menurut } \\
\text { Kepekaannya }\end{array}$} & \multicolumn{2}{|c|}{$\begin{array}{l}\text { Intensitas Hujan } \\
\text { Harian Rata-Rata }\end{array}$} & \multirow{2}{*}{$\begin{array}{l}\text { Total } \\
\text { Skor }\end{array}$} & \multicolumn{2}{|c|}{ Arahan Penggunaan Lahan } \\
\hline & $(\%)$ & Skor & Jenis & Skor & $\mathrm{mm} /$ hari & Skor & & $\begin{array}{c}\text { Dalam } \\
\text { Kawasan } \\
\text { Hutan }\end{array}$ & Luar Kawasan Hutan \\
\hline 1 & 69 & 100 & Andosol & 60 & 16,80 & 20 & 180 & $\begin{array}{c}\text { Hutan } \\
\text { lindung }\end{array}$ & - \\
\hline 2 & 55 & 100 & Andosol & 60 & 16.80 & 20 & 180 & $\begin{array}{l}\text { Hutan } \\
\text { lindung }\end{array}$ & - \\
\hline 3 & 40 & 80 & Andosol & 60 & 16,80 & 20 & 160 & $\begin{array}{l}\text { Hutan } \\
\text { lindung }\end{array}$ & - \\
\hline 4 & 68 & 100 & Andosol & 60 & 16,80 & 20 & 180 & - & Kawasan lindung \\
\hline 5 & 57 & 100 & Andosol & 60 & 16,80 & 20 & 180 & - & Kawasan lindung \\
\hline 6 & 40 & 80 & Andosol & 60 & 16,80 & 20 & 160 & - & Kawasan penyangga \\
\hline 7 & 23 & 60 & Andosol & 60 & 16,80 & 20 & 140 & - & Kawasan penyangga \\
\hline 8 & 5 & 20 & Andosol & 60 & 16,80 & 20 & 100 & - & $\begin{array}{l}\text { Kawasan budidaya } \\
\text { tanaman tahunan }\end{array}$ \\
\hline 9 & 20 & 60 & Latosol & 30 & 16,80 & 20 & 110 & - & $\begin{array}{l}\text { Kawasan budidaya } \\
\text { tanaman tahunan }\end{array}$ \\
\hline 10 & 12 & 40 & Latosol & 30 & 16,80 & 20 & 90 & - & $\begin{array}{l}\text { Kawasan budidaya } \\
\text { tanaman tahunan }\end{array}$ \\
\hline 11 & 2 & 20 & Latosol & 30 & 16,80 & 20 & 70 & - & $\begin{array}{l}\text { Kawasan budidaya } \\
\text { tanaman tahunan }\end{array}$ \\
\hline 12 & 52 & 100 & Andosol & 60 & 16,80 & 20 & 180 & - & Kawasan lindung \\
\hline 13 & 35 & 80 & Andosol & 60 & 16,80 & 20 & 160 & - & Kawasan penyangga \\
\hline 14 & 7 & 20 & Andosol & 60 & 16,80 & 20 & 100 & - & $\begin{array}{l}\text { Kawasan budidaya } \\
\text { tanaman semusim }\end{array}$ \\
\hline 15 & 50 & 100 & Latosol & 30 & 16,80 & 20 & 150 & - & Kawasan penyangga \\
\hline 16 & 33 & 80 & Latosol & 30 & 16,80 & 20 & 130 & - & Kawasan penyangga \\
\hline 17 & 25 & 60 & Latosol & 30 & 16,80 & 20 & 110 & - & $\begin{array}{l}\text { Kawasan budidaya } \\
\text { tanaman semusim }\end{array}$ \\
\hline 18 & 10 & 40 & Latosol & 30 & 16,80 & 20 & 90 & - & $\begin{array}{l}\text { Kawasan budidaya } \\
\text { tanaman semusim }\end{array}$ \\
\hline 19 & 1 & 20 & Latosol & 30 & 16,80 & 20 & 70 & - & $\begin{array}{l}\text { Kawasan budidaya } \\
\text { tanaman semusim }\end{array}$ \\
\hline
\end{tabular}

Pengecualian pada unit lahan 3 dengan skor berada di bawah 175 yang merupakan kawasan dengan kriteria pelindung mata air dan memang telah ditetapkan sebagai hutan lindung oleh pemerintah.

Kawasan luar hutan dibagi menjadi empat yaitu kawasan lindung, kawasan penyangga, kawasan budidaya tanaman tahunan dan kawasan budidaya tanaman semusim. Untuk arahan penggunaan lahan berupa kawasan lindung tersebar di wilayah Desa Antapan, Bangli, Baturiti dan Angseri dengan penggunaan lahan berupa kebun campuran yaitu pada unit lahan 4 dan 5 dan sawah pada unit lahan 12 dengan kemiringan lereng berkisar 52 sampai 68 $\%$. Arahan penggunaan lahan berupa kawasan penyangga tersebar di wilayah Desa Bangli, Candikuning, Baturiti, Batunya dan Antapan dengan penggunaan lahan saat ini berupa kebun campuran dan sawah beririgasi yaitu pada unit lahan 6, 7, 13, 15 dan 16 dengan kemiringan lereng berkisar 23 sampai $50 \%$.

Arahan penggunaan lahan berupa kawasan budidaya tanaman tahunan tersebar di wilayah Desa Candikuning, Angseri, Apuan, Antapan, Mekarsari dan Perean dengan penggunaan lahan berupa kebun campuran dengan kemiringan lereng berkisar 2 sampai 20 \%terdapat pada unit lahan 8, 9, 10 dan 11. Arahan penggunaan lahan berupa kawasan budidaya tanaman semusim tersebar pada wilayah desa Batunya, Baturiti, Apuan, Mekarsari dan Luwus dengan penggunaan lahan berupa sawah beririgasi dengan kemiringan lereng berkisar 1 sampai $25 \%$ yaitu terdapat pada unit lahan 14, 17, 18 dan 19. 


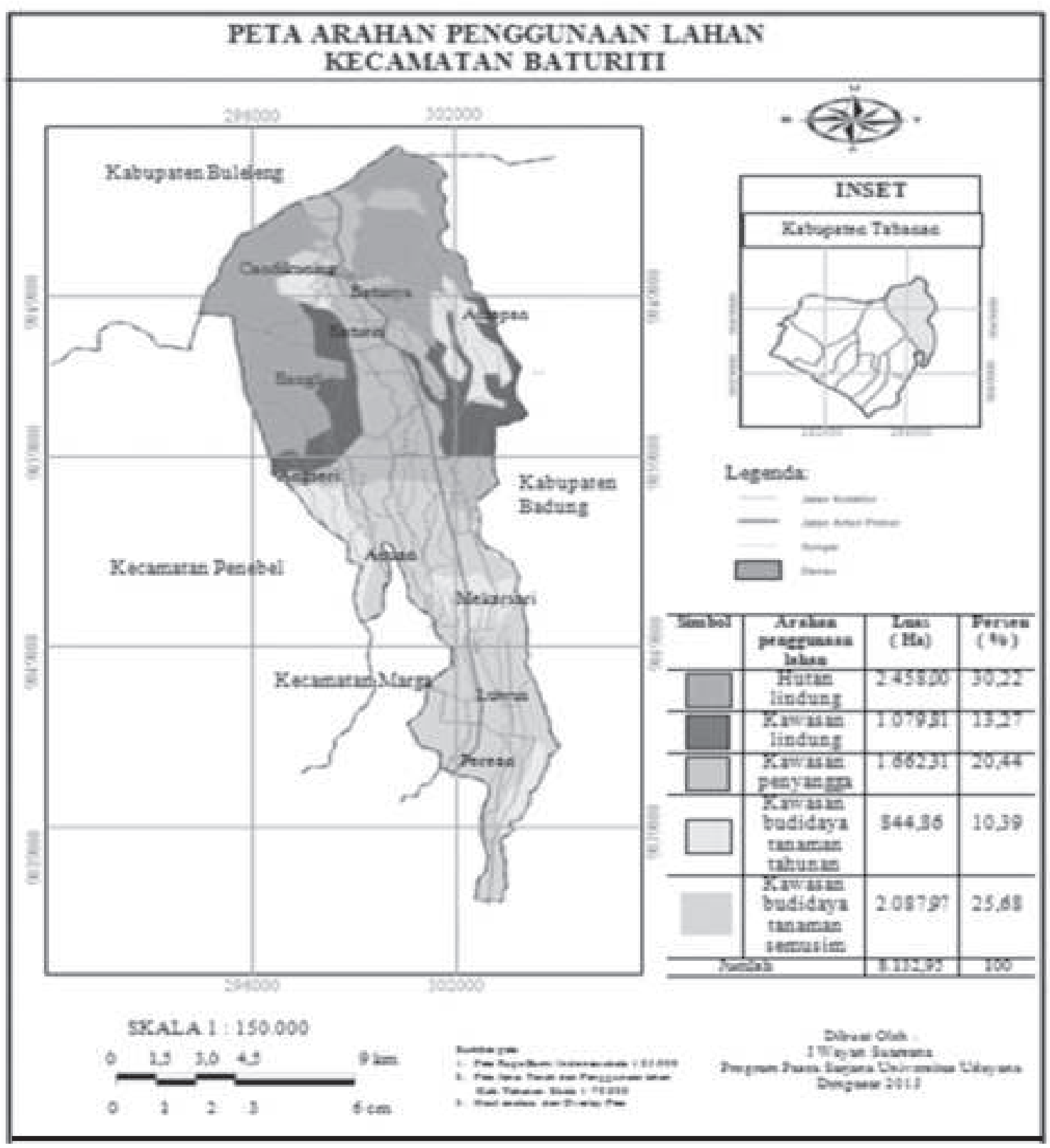

Gambar 3. Peta Arahan Penggunaan Lahan Kecamatan Baturiti

\section{SIMPULAN DAN SARAN}

\subsection{Simpulan}

1. Tingkat erosi yang terjadi di Kecamatan Baturiti tergolong sangat ringan sampai sangat berat. Tingkat erosi sangat ringan seluas 11,70 ha $(0,14$ \%) dengan peenggunaan lahan berupa hutan, sedangkan erosi ringan seluas 5.221,56 ha $(64,20$ $\%$ ) dengan penggunaan lahan berupa hutan dan sawah. Erosi dengan tingkat sedang seluas 88,10 ha $(1.08 \%)$ dengan penggunaan lahan berupa sawah, sedangkan tingkat erosi berat seluas 616,20 ha $(7,58 \%)$ dengan penggunaan lahan berupa kebun campuran dan sawah. Tingkat erosi sangat berat dengan luas 2.195,39 (27,00 $\%$ ) dengan penggunaan lahan berupa kebun campuran.
2. Tindakan konservasi tanah dan air yang dapat direncanakan di Kecamatan Baturiti pada unit lahan dengan nilai erosi yang melebihi nilai erosi yang ditoleransikan yaitu berupa kebun campuran, tajuk bertingkat, penutup tanah bervariasi dengan kerapatan tinggi, penanaman menurut kontur, teras bangku kontruksi baik dan penggunaan mulsa sisa tanaman 6 ton/ha/ tahun. Kebun campuran dengan tajuk bertingkat dan penutup tanah bervariasi dengan kerapatan tinggi dan penbuatan teras bangku kontruksi baik dan sawah beririgasi dengan teras bangku kontruksi baik.

3. Klasifikasi kemampuan lahan yang ada di Kecamatan Baturiti terdiri enam kelas kempuan lahan yaitu kelas II seluas 1.489,39 ha (18,32 $\%)$, kelas III seluas 827,39 ha $(9,95 \%)$, kelas IV 
seluas 830,15 ha $(10,21 \%)$, kelas VI seluas $1.373,79$ ha $(16,89 \%)$, kelas VII seluas1.453,92 (16,89 \%) dan kelas VIII seluas 2.176,31 ha (26,76 $\%)$, dengan faktor pembatas berupa kepekaan erosi, ancaman erosi, tekstur tanah, drainase dan kemiringan lereng.

4. Arahan penggunaan lahan di Kecamatan Baturiti untuk kawasan dalam hutan diarahkan untuk kawasan hutan lindung seluas 2.458,00 ha (30,22 \%). Pada kawasan di luar hutan diarahkan untuk kawasan lindung seluas $1.079,81$ ha $(13,27 \%)$, sedangkan arahan penggunaan lahan berupa kawasan penyangga seluas $1.662,31$ ha $(20,44 \%)$. Arahan penggunaan lahan berupa kawasan budidaya tanaman tahunan seluas 844,86 ha (10,39\%) dan arahan penggunaan lahan berupa kawasan budidaya tanaman semusim seluas $2.087,97$ ha $(25,68 \%)$.

\subsection{Saran}

1. Lahan dengan nilai erosi yang melebihi nilai dari erosi yang dapat ditoleransikan sangat memerlukan tindakan konservasi tanah dan air, yaitu berupa peningkatan jumlah tanaman dan kombinasi tanaman dengan kerapatan tinggi agar dapat melindungi tanah dari butiran butiran air hujan yang jatuh. Di samping itu dapat dilakukan pembuatan teras dengan kontruksi baik, penggunaan mulsa sisa tanaman yang banyak sehingga dapat mengurangi erosi yang terjadi. Dengan demikian nilai erosi yang terjadi nilainya bisa dibawah nilai erosi yang dapat ditoleransikan.

2. Lahan dengan tingkat erosi sangat berat sangat diperlukan pengelolaan jenis tanaman dan tindakan konservasi yang sangat tepat seperti pola tanaman dengan tumpang sari, penggunaan mulsa yang banyak dan pembuatan teras dengan kontruksi baik dengan tanaman pengaut teras.

3. Lahan dengan nilai erosi yang tidak melampaui nilai erosi yang dapat ditoleransikan perlu dijaga dan dipertahankan, apabila memungkinkan erosi yang terjadi bisa diperkecil yaitu dengan cara mempertahankan atau memperbaiki tindakan pengelolaan tanaman dan tindakan konservasi tanah yang telah dilakukan.

4. Dengan diketahuinya klasifikasi kemampuan lahan yang ada, sehingga pemanfaatan lahan bisa tepat dan benar sesuai dengan kelas kemampuan lahan yang ada, sehingga tidak mengakibatkan kerusakan pada lingkungan.

\section{DAFTAR PUSTAKA}

Adnyana, I. W.S, dan A. R. As-syakur. 2011. Kelas Kemampuan Lahan dan Arahan Penggunaan Lahan Provinsi Bali. Dalam : Adnyana, I. W. S., Arthana, I. W., dan As-syakur, A. R., (editors). Perubahan Penggunaan Lahan dan Daya Dukung Lingkungan. Udayana Univesity Press dan Pusat Penelitian Lingkungan Hidup (PPLH). Universitas Udayana. Denpasar, Hal. 52-64.

Arsyad.S. 1989. Konservasi Tanah dan Air. Bogor: IPB Press.

Badan Pusat Statistik Tabanan. 2013. Kecamatan Baturiti Dalam Angka 2012. Kabupaten Tabanan

Badan Lingkungan Hidup Daerah Kabupaten Tabanan. 2014. Buku Data Status Lingkungan Hidup Kabupaten Tabanan. Tabanan-Bali.

Bols. P. L. I978. The Iso-erdent Map Of Java and Madura. Report On Belgian Technical Assistance Project ATA 105. SRI Bogor.

Murtianto, H. 2013. Evaluasi Kemampuan Lahan Untuk Arahan Penggunaan Lahan. Jurnal Nasional Ecopedon. Vol. 2 ( 1 ) : 2-15.

Rahim, S. E. 2003. Pengendalian Erosi Tanah dalam Rangka Pelestarian Lingkungan Hidup. Jakarta: Bumi Aksara.

Wischmeir, W. H. and D. D. Smith. 1978. Predicting Rainfall Erosion Lossess: A guide to Conservation Planning. USDA Agric. Handbook No.537. Washington DC. 